\title{
STRATEGIES FOR IMPROVING THE STANDARD OF WOMEN EMPOWERMENT PROGRAMMES IN NIGERIA
}

\author{
OLOMUKORO, O. CAROLINE
}

Department of Adult \& Non-Formal Education, University of Benin, Nigeria.

\begin{abstract}
This paper examines the strategies for improving the standard of women empowerment programmes in Nigeria which have not been adequately maintained and sustained over the years. The paper shows that despite the laudable programmes put in place by education agencies to elevate the status of women, certain factors tend to hinder access to the successful utilization of education opportunities by women. The paper discusses the concepts of empowerment and development, highlights the empowerment programmes and the situational analysis of women educational status and recommends, among others, that the empowerment of women should start from the grassroots by organizing training programmes with skill acquisition centres for women by government agencies and other educational stakeholders. The girl-child should be properly enrolled in schools early enough in order to overcome the primary set back of illiteracy. Education requires the concerted effort of all concerned as opposed to abandoning the responsibility to government alone.
\end{abstract}

Keywords: Standard, Education, Development, Women Empowerment, Programmes.

\section{Introduction}

All over the world, countries invest in education because it facilitates personal and social development. It is the potent instrument for the development and transformation of any society. It has also been recognized as a fundamental pillar of human right, democracy, sustainable development and peace. Education whether formal or non-formal has been seen as the foremost instrument for empowerment. It is the bedrock of women empowerment. Olaleye (2008) has also observed that education as a process, has become a very important means of empowering women with basic knowledge and skills, so that they can become co-partners in development. In addition, Adesanya (2006) remarks that education is critical to empowering women in all aspects and it is increasingly seen as an instrument of empowerment.

Several landmark conferences, including the 1994 International Conference on Population and Development, held in Cairo, and the 1995 Fourth World Conference on Women in Beijing, placed women's education and empowerment at the centre of development efforts. Similarly, the third goal of the Millennium Development Goals (MDGs) addressed women's needs. The goal stresses the import of women empowerment and gender equality. The United Nations Millennium Development is the most recent body of International work that addresses and reaffirms the equality of women. Additionally, Kwapong (2005) points out that women have an enormous influence on the well-being of their families and societies, but their potential is not fully realized because of the discriminatory social norms, incentives and legal institutions. Hence, there is an urgent need to empower the female folk and ensure that the standard of the various programmes are improved upon and maintained.

It is no longer in doubt that women constitute the majority of adult illiterates in the world. The Education For All Global Monitoring Report (2008) lent support to this view point that about 774 million adults lack literacy skills, one in five adults is still not literate and two-thirds of these adults are women. Buttressing this assertion further, the 2006 National Population Census Report puts the female population at 68.3 percent out of a total of 
about 140,000,000 Nigerians and a majority of them are illiterates. Similarly, the Human Development Report of July 2014 in commemoration of the International Literacy Day September $8^{\text {th }}$, indicated that Nigeria has a literacy rate of 61 percent and a majority of the illiterate population are women. Nigeria is ranked $184^{\text {th }}$ out of 194 countries in the world in terms of literacy attainment in 2012. The United Nations Educational, Scientific and Cultural Organization (UNESO) states that an estimated 40 to 45 million persons in Nigeria are illiterate. In 2015, the number increased to about 54 million. The document further indicated that of the over 757 million adults worldwide who still lacked basic literacy skills about two-thirds of them are Nigerian women, and the third-world countries. The 2013/2014 Global Monitoring Report (GMR) states that Brazil, China, Indonesia have all attained a 90 percent literacy rate, whereas Nigeria has less than 70 percent.

According to Akande (2003) in Olomukoro (2014) education in particular increases a person's ability to participate in society and to improve the quality of life and standard of living. Education is therefore, perhaps more important for women than men, especially in the Sub-Saharan Africa, where economic and social development are grossly constrained by rapid population growth and inadequate development of the human resource base. Women are foundations of life due to their multiple and critical roles in the family as homemakers, caretakers and caregivers. This explains why Abaji (2008) argues that education more than any other instrument in the world, is empowering and for the female gender, nothing can be more empowering than the instrument of Education. It is Education that gives information and skills for effective participation of individuals on issues in the society. The United Nations Nairobi Forward Looking Strategies (1985) stressed that education is the starting point for women advancement in the different fields of human endeavour. It is the basic tool that should be given to women in order to fulfill their role as full members of the society. In a similar vein, Ojobor (2008) observes that the educational empowerment of Nigerian women is the springboard to every other form of empowerment, be it political, social, economic and cultural.

The National Policy on Women approved and adopted in April 2000 states that women's educational status in any nation correlates with its level of development (Women Watch, 2005). Fasokun (2008) indicates that education does not only provide basic knowledge and skills to improve health and livelihoods, but it empowers women to take their rightful place in the society and in the developmental process. Bereday in Afonja (2003) says that education is truly a mirror of the level of development and the aspiration of any people. The author further notes that education is a means of advancing people in terms of giving them knowledge, skills, attitude and aptitude necessary for expanding their potentials. Education remains the bedrock for a sustainable development.

Women empowerment involves developing their mental and physical capacity, power or skills for them to operate meaningfully in their social, economic and political milieu; thereby experiencing a more favorably level of recognition and subsequently enhance their statuses. Education is a fundamental right for all, including girls and women. Women have been known to have contributed in very many ways to the development and betterment of the society and yet women are still less educated and under-represented in all spheres of human endeavours compared to their male counterparts. (Kester and Gbenro, 2008; Osokoya, 2008). 
Given that women constitute over fifty percent (50\%) of the world's population including Nigeria with about two-thirds of them as non-literates, their empowerment is therefore crucial for national development. For instance, the UNESCO (2003) records that the literacy rate for Nigerian girls and women stood at $47 \%$ while that of males was $67 \%$, yet the females form about 50 percent of the population. Their development is unarguably imperative because harmonious and sustainable development requires the participation of all the citizens of a nation. It must be emphasized that no nation can make impressive progress in terms of development if her women folk remain ignorant, excluded and marginalized.

Women and girls globally constitute the largest single category of persons denied full and equal opportunities of education for all. According to the 2006 Population Census Report, there are 71,709,859 million males and 68,293,633 million females in Nigeria. Two-thirds of the female population is illiterate. This is further buttressed by the Education for All Global Monitoring Report (2008) that more than 22 million people in Nigeria are illiterate, 65 percent of who are women. As citizens of this country, women form a high percentage of the population in Nigeria and they need to be empowered to contribute their quota to the development of the country. It is against this background of the lop sided women empowerment programmes that this paper examines strategies for raising the standard of women's empowerment programmes in Nigeria.

\section{Clarification of key concepts}

\section{Empowerment:}

The word empowerment captures the sense of gaining control and participating in decision making. At the core of the concept of empowerment is the idea of power. In defining the term empowerment, Karl (1995:14) explained that power means

- $\quad$ having control or gaining further control

- $\quad$ having a say and being listened to

- $\quad$ being able to define and create from a woman's perspective,

- $\quad$ being able to influence social choices and decisions affecting the whole society, and

- $\quad$ being recognized and respected as equal citizens and human beings with a contribution to make.

In the view of Nigel and Werner (2001), the concept of empowerment in an individual or a social group, presupposed that a state of social oppression exists which has disempowered those in the group, by denying them the opportunities or resources which have defined them as inferior humans; thus lowering their self esteem. As a general goal, empowerment has been described as a political and economic process which increases individual and group power, self reliance and strength.

Similarly, Adesanya (2006) pointed out that empowerment is the acquisition of more control over decision which affects one's life. It refers to a combination of increased awareness of strategy and an ability and capacity to act. He further stated that empowerment occurs only through action. Individual or psychological power does not exist apart from action, control or influence in individual's life. It is the combination of the thinking, learning and acting which results in a sense of being empowered. Women 
empowerment according to Kwapong (2005), comprised building their capacity or making the best of their lives for governance and socio-economic achievement. The author further stressed that access to literacy or education, information, knowledge, resources natural or material resources, productive skills, and capital facilitate the empowerment of Women.

Fadeiye and Olanegan (2001:66) viewed Women empowerment as:

a process of enabling women to develop the capacity to actualize their potentials That women should be looked at as individuals that possess some hidden potentials for greatness and so should be encouraged to develop such to the fullest.

Enemuo (1999:226), quoting Sandbrook and Halfani, perceived empowerment as a

multidimensional process involving the
transformation of the economic, social,
psychological, political, and legal circumstances of
the powerless. In the specific case of women,
empowerment entails not only positive changes in
these critical respects but also the dismantling of
the cultural norms and traditional practices that
devalue disempower and dispossess women. The
process must necessarily also include the expansion
of women's access to educational opportunities
facilities for skills acquisition and positions of
authority.

Shetty (1992) after attempting a review of literature came to the conclusion that empowerment is easy to experience but complex to define, explaining further that while it is difficult to define empowerment it can be understood when its manifestation becomes obvious. Thus an empowered individual is one who experiences a sense of self confidence and self worth; who critically analyses his or her social political environment; and who is able to exercise control over decisions that affect his or her life.

For the purpose of this paper, empowerment may be considered as a multi-dimensional process involving the transformation of the economic, social, psychological, political, and legal circumstances of the powerless. Women empowerment is the process of improving the human capital of women for effective participation in all aspects of development of a nation. To dismantle the cultural norms and traditional practices that disempowered women, they need to collectively come together to recognize and address the gender issues which stand in the way of their empowerment. The process must also include the expansion of women's access to educational opportunities, skill acquisition, and positions of authority.

\section{Development}

The concept of development has been viewed from different angles including social, economic, political and cultural. The social aspect of development deals with social 
changes accompanying development such as greater access to education, improved reproductive health services and so on. Economic aspects imply participation in producing the nation's wealth through economic activities. The political domain deals with participation in political activities or occupying positions of authority in the civil service, judiciary or in the executive arm of government where important decisions are made. The cultural aspect is concerned with the way of life of the people generally in terms of language, dressing, religion, dance, drama, and painting among others. Development, within the national outlook, depicts positive change or growth in socioeconomic and political conditions or situations of the society. Development is a process of economic, social, political and cultural change engineered in a given society by the efforts of all stakeholders both internal and external. In a similar perspective, Akinpelu (1992) noted that people are the subjects and objects of development. In other words, development is of the people, by the people and for the people.

Furthermore, Ghai (1988), quoted in Fadeyi (1995), viewed development in terms of human potentials and capabilities in the context of relations with other social groups. He further emphasised that development means greater understanding of social, economic, and political processes, enhanced competence to analyse and solve the problems of dayto-day living, expansion of manual skills, greater control over economic resources, restoration of human dignity, self-respect, and equality. The thrust is on the realization of human potential expressed in social emancipation and enhancement of moral, intellectual, and technical capabilities. This is the kind of development women should crave for.

\section{Empowerment Programmes for Women}

Development programmes are designed to improve living conditions and to allow women full participation in the processes that will enhance their development at home, community and national levels. The main objective is to alleviate the burden of women daily lives through appropriate empowerment programmes (for example basic education, skill development, access to information regarding health, nutrition status and so on),

In Nigeria, like other developing countries of the world, different programmes are embarked upon, sponsored by international organizations or national initiatives in collaboration with the state and local governments for the benefit of all women. In a bid to improve the welfare, the civic, political, cultural, social and economic development of women in Nigeria, the Decree No. 30 of 1989, which established the National Commission for Women was promulgated to formulate a national policy on women and development. All programmes for women are carried out by this Commission. The objectives of the Commission are to:

- $\quad$ promote the welfare of women in general;

- $\quad$ promote the full utilization of Women in the development of human resources and to bring about their acceptance as full participants in every phase of national development, with equal rights and corresponding obligations

- $\quad$ promote responsible motherhood and maternal health of Women;

- stimulate actions to improve women's civic, political cultural, social and economic education;

- $\quad$ support the work of non - government organizations and to play a coordinating role between government and Nigerian Women organizations; 
- $\quad$ encourage the sense and essence of cooperative societies and activities amongst women both in urban and rural areas and stimulate in them creative entrepreneurship in the field of cottage and small - scale industries;

- $\quad$ formulate and propagate moral values within the family unit and in the public generally and to establish programmes with institution and organizations to inculcate moral education in women and children; and work towards the total elimination of all social and cultural practices tending to discriminate against and dehumanize womanhood

In 1986, the Blueprint on Women Education in Nigeria was launched, followed by the setting up of Women education units of the Federal and State Ministry of Education. These units cater for both rural and urban women who desire to further their education. Attention is also focused on women with special needs such as nomadic and riverine fisher-folk women, women in pudah, dropouts of all categories especially teenage single parents. The overall aim of the blueprint is to avail all Women equal educational opportunities irrespective of their age, locality, creed or social status. The women education units also run women's vocational centres in all local government areas in the skills of cloth weaving, tie and dye, farming, food processing and preservation, dress making, cooking, cosmetology, secretarial, and computer studies.

The National Commission for Mass Literacy and Non-Formal Education (NMEC) was set up in 1991 by the Federal Government, charging it with the task of eradicating illiteracy in the country. Women are specially targeted in the programmes of the Commission with mass literacy classes being conducted in all nooks and crannies of the country.

Other programmes or projects undertaken by the federal government to strengthen girls' education with international development partners like UNESCO, World Bank, DFID among others are:

- $\quad$ provision of adult literacy and girls' education through the National Commission for Mass Literacy Adult and Non- Formal Education (through education radio programmes, provision of supportive materials and awareness creation).

- $\quad$ provision of library books to primary schools by the World Bank.

The United Nations Girls Education Initiative (UNGEI), which promoted the enrolment of more girls in school under the African Girls Education Initiative (AGEI) with financial support of the Norwegian government, was also put in place to promote women's status (Opeke, 2008). Some women empowerment initiatives are presented in Table 1 below:

\section{Women Empowerment Initiatives}

Table 1

\begin{tabular}{llll}
\hline S/No. & Programmes & Date & Objectives \\
\hline 1 & $\begin{array}{l}\text { Better life for } \\
\text { Rural Women } \\
\text { Programme }\end{array}$ & $\begin{array}{l}\text { Launched in 1987 Maryam } \\
\text { by } \\
\text { Babangida }\end{array}$ & $\begin{array}{l}\text { Set up to enhance the quality of life of } \\
\text { rural women. It harnessed the } \\
\text { potentials of rural women and impacted } \\
\text { positively on the economic activities } \\
\text { and incomes. }\end{array}$ \\
2 & $\begin{array}{l}\text { Family Support } \\
\text { Programme }\end{array}$ & $\begin{array}{l}\text { Launched } \\
\text { September, 1994 }\end{array}$ & $\begin{array}{l}\text { Established sequel to the United } \\
\text { Nations declaration in1994 as the }\end{array}$ \\
\hline
\end{tabular}




\begin{tabular}{|c|c|c|c|}
\hline & & $\begin{array}{l}\text { by } \quad \text { Maryam } \\
\text { Abacha }\end{array}$ & $\begin{array}{l}\text { International year of Family It focused } \\
\text { on empowering women to take their } \\
\text { proper place in the family. }\end{array}$ \\
\hline 3 & $\begin{array}{l}\text { Lift Above } \\
\text { Poverty } \\
\text { Organization } \\
\text { (LAPO). } \\
\text { Innovative } \\
\text { credit and non- } \\
\text { credit } \\
\text { empowerment } \\
\text { programme }\end{array}$ & $\begin{array}{l}\text { Established in } \\
1987 \text { and } \\
\text { formally } \\
\text { incorporated as a } \\
\text { non-governmental } \\
\text { non-profit } \\
\text { community } \\
\text { development } \\
\text { organization in } \\
1993\end{array}$ & $\begin{array}{l}\text { It seeks to promote economic } \\
\text { empowerment of the poor especially } \\
\text { women by improving their socio- } \\
\text { economic status through provision of } \\
\text { financial services. It focuses on } \\
\text { empowerment of women. }\end{array}$ \\
\hline 4 & $\begin{array}{l}\text { Idia } \\
\text { Renaissance } \\
\text { Skill } \\
\text { Acquisition } \\
\text { Centre }\end{array}$ & $\begin{array}{l}\text { Established in } \\
1999 \text { by Former } \\
\text { first lady of Edo } \\
\text { State Mrs Eki } \\
\text { Igbinedion }\end{array}$ & $\begin{array}{l}\text { Aimed at rehabilitating victims of } \\
\text { female traffickers and provide training } \\
\text { and enlightenment for vulnerable and } \\
\text { susceptible groups in the society. }\end{array}$ \\
\hline 5 & $\begin{array}{l}\text { FG Flags -off- } \\
\text { girls/women } \\
\text { Empowerment } \\
\text { G-WIN project } \\
\text { Umuahia, Abia } \\
\text { State }\end{array}$ & $\begin{array}{l}\text { Launched in } \\
\text { February } 11,2014 \\
\text { by former } \\
\text { Minister of Water } \\
\text { Resources }\end{array}$ & $\begin{array}{l}\text { Aimed at creating employment and } \\
\text { wealth to alienate poverty among the } \\
\text { female folks. }\end{array}$ \\
\hline 6 & $\begin{array}{l}\text { Women } \\
\text { Empowerment } \\
\text { G-WIN Project } \\
\text { in Abuja }\end{array}$ & $\begin{array}{l}\text { Launched by } \\
\text { former President } \\
\text { Jonathan in } \\
\text { March 9, } 2015\end{array}$ & $\begin{array}{l}\text { A Federal government initiative to } \\
\text { empower women and girls in Nigeria. } \\
\text { It reverses gender -specific gap and } \\
\text { also close the digital gender. }\end{array}$ \\
\hline
\end{tabular}

Source: $\quad$ Olomukoro (2015).

Several women empowerment programmes or initiatives have been embarked upon by successive governments, private organizations and non-governmental organizations in Nigeria. These include ; Better Life for Rural Women, Family Support Programme, Lift Above Poverty Organization (LAPO), India Renaissance Skill Acquisition Centre, FG Flags -off-girls/women Empowerment G-WIN project among others.

The women have benefitted from these empowerment programmes immensely. For example, the Better Life for rural women initiated by the late First Lady Maryam Babangida following the outcome of Beijing Conference of 1985 improved the socioeconomic status of women through the provision of financial services via cooperatives, cottage industries, farms and gardens, shops and market, women centres and social welfare programmes. The Better life programme according to Ijere (2001) has led to the establishment of Ministry of Women Affairs in all the states of the federation. Credit and other inputs flow to rural organizations more than ever before. It has stimulated and motivated rural women towards achieving better living standards, educate rural women on simple hygiene, family planning, importance of child care and increased literacy rates. The Better Life programme made tremendous impact with regard to poverty alleviation through the distribution of fertilizers to women, formation of cooperatives and the establishment of processing mills. The success of the programmes was however short 
lived. The programme was not only hijacked by position seeking individuals but the resources set aside for the programme were diverted and used for personal enrichment.

The Family support Programme which was the private initiative of Maryam Abacha launched in 1994 replaced the better Life for Rural Women. This was inaugurated following the United Nations declaration in 1994, as the International year of Family. This also improved the lots of women economically.

Lift Above Poverty Organization (LAPO) started in 1987 in Ogwashi- Uku, Delta State by Dr Godwin Ehigiamusoe while working as a rural co-operative officer and was formally incorporated as a non-profit, non-governmental organization in 1993. LAPO focuses on the empowerment of the poor and vulnerable people especially women in the areas of their social, health and economic well being. LAPO is one of the top 100 organizations, adding value to socio-economic life of the people in Edo State (Benin Business Diary Annual, 2015). The document further indicated that LAPO assists clients in overcoming problems of poverty, illiteracy and gender inequality by providing training, sensitization and advocacy.

The government empowerment initiatives improved the lives of women generally in the socio-economic aspect but lack continuity and sustainability. For example, the Better Life for rural women programme was short lived and was replaced by Family Support Programme. The Idia Rennainsance initiated by former Mrs. Eki Igbinedion was not followed up by the successive government. The women empowerment programmes GWIN Project launched at Umuahia by former Minister of Water Resources in 2014 and by former President Good Luck Jonathan at Abuja in 2015 were all received with great enthusiasm and high expectations but what has become of such programmes remain a puzzle especially now that Jonathan is out of office. This has been the bane of the society. It is unfortunate that Nigerian First ladies keep establishing all kinds of programme that will not sustain outside office. There is also a diversion of funds to satisfy personal interest. Consequently, there is need for new strategies to be put in place in order to improve and sustain the empowerment programmes.

\section{Situational Analysis of Women Educational Status in Nigeria}

The level of education of women is low in Nigeria most especially in Northern parts of Nigeria. The National Literacy Survey ((2010) conducted by the National Bureau of statistics in Nigeria estimates that adult literacy rate is 56.9 percent with huge variations between States (Lagos, $88.3 \%$ and Yobe only 14.4\%) regions (urban $74.6 \%$ and rural $48.7 \%$ ) and gender (male $65.1 \%$ and female $48 . \%$ ). Nigerian women still have a long way to go in achieving the objectives of the empowerment educational programmes spelt out earlier in this paper. The goal of women empowerment is to be directed towards restoring the dignity of womanhood as sound, intelligent, and functional members of the society. It is also to elevate the status of women and to eliminate all forms of cultural, social, economic and political discriminations against them, so that they can be at the centre not at the periphery of development process.

Unfortunately, certain factors tend to hinder access to the successful utilization of education opportunities by women. The dearth of accurate data on women educational status makes evaluation and assessment of their educational programmes difficult in Nigeria. However, the available data show the commendable efforts of the various bodies 
engaged in adult literacy and women education programmes even though the overall progress being made is slow.

\section{Needs for Women Education}

Education is an agent of change in the status of women and in playing an interventionist role in their empowerment (Aromolaran, 2010). Singh (1985) and Osuala (1992) contended that giving women education will create new assets for them by helping them to help themselves, It will create awareness which will not only help them to solve their problems but also help them to understand the word, read the word and control their world (Bhasin 1985).

Women education is a type of education received by women which would make them become aware of themselves and their capacity to exploit their environment. Babalola (1998) cited in Aromolaran (2010), highlighted the objectives of women education as follows:

- foster in women the spirit of self-discipline, hard work, cooperative and respect for constituted authority;

- facilitate the evolution of responsible well-informed and self- reliant Nigerian women;

- $\quad$ create adequate and functional political literacy amongst women;

- make Nigerian women fully aware of their rights and duties to respect the right of others;

- $\quad$ sensitize the women to the -functions and obligations to government; and

- $\quad$ create in the women an awareness of the provisions of the Nigerian constitution.

However, several factors have been identified as militating against women education and made it seem an imaginary thing that has placed women as second fiddle to men. These factors include organization patterns, discriminatory practices against women in the labour market, social factor, political factor, religious and educational factors.

The low status accorded women in the society is attributed to lack of access to education. However, this situation has assumed a new dimension. Most women are no longer confined to the home front but combined household chores with social and economic responsibilities and act as bread winners of their families (Salami and Uko-Aviomah, 2005). Some women are now goal attainers competing favourably with men. The society is becoming more complex and has witnessed a lot of changes in every sphere of living as noted in the political, economic, social, and technological domains. So also the roles of women (reproductive, production, and emancipatory roles) have also changed considerably. Women need education to participate in developmental tasks. Education of women is necessary for social, economic and political development.

\section{Strategies for Raising the Standard of Empowerment Programmes in Nigeria}

In discussing the strategies to be adopted for women's empowerment in Nigeria, Okeke (1995) itemized four major areas. These include education, participation in cash economy, participation in politics, and a review of the laws on the status of women. Okeke's suggestion corroborated McDowell's (1985) view that "women must have a greater access to information, education, employment and political participation". 
Education of women will equip them with more valuable skills and competences which will enable them perform their duties more effectively. It is noteworthy that many educated women have made impressive achievements. For example, Professor AleleWilliams was the first femaleVice-Chancellor in Nigeria at the University of Benin, Benin City (1985 - 1992), Dr. Ngozi Okonjo Iweala and her dynamic reforms and leadership qualities in the finance sector, and late Professor Dora Akunyili of NAFDAC and her fight against fake drugs, to mention just a few.. This has prepared them for noble and rewarding roles in social, economic and political spheres. Abawua quoted in Aramolaran (2010), maintained that educated women who are gainfully employed are sources of income to their homes with their earnings as they are able to augment financially what the man provides. Therefore, there is no doubt that a woman's access to education will go a long way to improve her poor economic status as well as that of the entire family and the nation as a whole. Therefore, the following suggestions will bring about improvement in girls' and women's educational programmes.

First and foremost, the process of empowering the Nigerian women and thus integrating her into the mainstream of the development must start from the grassroots. Government agencies and private organizations should organize training programmes with various skill acquisition units for rural woman. This will ensure financial independence and better standard of living. Parents, guardians and the society as a whole must allow and encourage their female children to enroll in schools early enough so that they will be able to acquire a proper awareness of their potential, rights and higher responsibilities in society. Local governments should particularly assume a special role in ensuring that female children are henceforth properly enrolled in primary schools to enable them overcome the primary hurdle of illiteracy.

Government should assist training centres with adequate funding by giving them interest free loans upon completion of the programme to enable them utilize the skills they have acquired. This will in the long run bring about economic development in the nation and improvement in the standard of living of women.

Adequate funding must be made available by government and private agencies towards maintaining and sustaining the already existing programmes so that available centres can be equipped with adequate human and material resources. It has been observed that availability of necessary resources in terms of instructors, equipment and infrastructures is a key to successful participation in vocational training programmes and this should be improved upon. This will go a long way to stimulate the effective participation of women in training programmes thereby leading to greater enrolment rate among the women folk.

Financial incentives like special scholarship award, soft tuition loans and other financial grants can be specifically granted to women by government, philanthropists in order to check talented and promising females from drifting away from education.

Special intervention schemes by government such as elimination of school fees, scholarships, establishment of community schools for girls and the training of women teachers are ways of strengthening empowerment programmes for women. Countries such as Bangladesh, Yemen, Morocco, Uganda and Brazil have recorded success stories by implementing such intervenion schemes. Such targeted efforts have translated into higher girls' school enrolments in their various countries. Nigeria should borrow a leaf from their experiences by adopting the strategies highlighted above. 
Financial aid can be obtained through government agencies and private organizations. Private organizations can source for fund through donations, launching, levies, sales of community resources, royalties, religious bodies, international organizations and charitable bodies. Inadequate funding by federal, state and local government is a serious problem facing education development in Nigeria especially the non-formal sector. At all levels, adult and non-formal education suffers serious under funding. That is why the private sector and women empowerment promoters including communities should seek alternative means of funding training programmes for women as enumerated above as government alone cannot do it. It must be a collective effort.

Political will, stronger national leadership and commitment are needed for effective and successful implementation of national plans and policies towards women's empowerment programmes in the country. It is a well-known fact, that the gender gap is wider at higher levels of education. It is not sufficient that girls merely sign up for school, they need to be retained to complete their education. Government, educators and communities must address issues such as gender stereotype which reinforce women's lower status, poor school quality and early marriage and child bearing which often cut short women's education by implementing national policies and budgetary allocations.

Government should set up a monitoring team to coordinate and monitor adequately all the training programmes for women in order to maintain standard and not just as a profitmaking venture.

Women should be mobilized at the grassroots level to participate in International Special days. For example, International Literacy day, September 8 every year and International Women Day, March 8. This will increase the awareness of the benefits of education among women since there is an overwhelming evidence of the benefits of educating the female folk worldwide.

Empowerment programmes for women should not be limited to feminine field only such as fashion design, catering, hair dressing among others. Women should be encouraged to delve into technical sector also by making available such programmes for the women folk in the society through government agencies, educators, private organizations, NGO and communities.

Empowerment programmes initiated by successive governments should be sustained and not allow to waste because such government is out of office. In other words, there should be continuity of programmes after each government must have left office. The issue of maintenance culture should be revisited and imbibed by government agencies and all stakeholders in Education so that the various empowerment programmes will not be abandoned and resources invested into the programmes wasted.

Government, non-government organizations, and public spirited individuals must embark on extensive enlightenment campaign with the use of posters, leaflets, fliers, brochures, which are to be widely circulated so as to disseminate the unquantifiable benefits of female education. Press releases, radio and television jingles must be adopted to demystify some unprogressive norms prevalent in the society. The continued effort of civic, social and religious leaders will ensure appreciable progress. 
Adult literacy programmes should be encouraged and adequately supervised. Post literacy programmes like preparing learners for Primary Six Leaving Certificate, Junior Secondary School and General Certificate Examination (GCE) and continuing education and training programmes should also be put in place to ensure the sustainability of basic skills which will guarantee greater income and more meaningful livelihood to millions of the hitherto disadvantaged citizen

Adequate instructional materials and facilities must be provided for programme implementation. Training and retraining programmes should be organized for facilitators and teachers for this will help to raise the quality of our educational programmes.

Women must organize themselves to meet the challenges of positive and meaningful roles in the struggle for national emancipation, development and progress through the acquisition of functional education which will usher in a new lease of life so that women and girls can face squarely the challenges of national development in the century.

Women must continue to seek and ask for their rights especially where either the constitution or other documents like National Policy on Women, CEDAW (Convention on the Elimination of all forms of Discrimination Against Women), Beijing Blueprint have made provisions.

Finally, if the struggle to elevate the status of women by according them increased political roles in the society must be achieved, the various women organizations and associations must form a coalition to fight all the discriminatory practices which stand in the way of their advancement. Women must be made to realize that lack of political power is responsible for their subordination in the society.

\section{Conclusion}

It has been established in this paper that education, formal or non-formal, is the prerequisite for women's empowerment. Women constitute a high percentage of the population and a majority of them are illiterate. In order to achieve the required standard in women empowerment programmes so that women can truly be empowered, women need greater access to educational opportunities, skill acquisition, and positions of authority. Women need to come together to recognize and address the gender issues which stand in the way of their empowerment so that they can effectively participate in all aspects of development.

\section{References}

Adesanya, L. A. (2006). Non-formal education, women and empowerment: A conceptual framework. Perspective in Education, 1 (22).

Afonja, A. F. (2003). Psycho-social Predictators for Workers Participation in Professional Continuing Education Programme in Lagos State. Unpublished Thesis, Adult Education Department University of Lagos, Nigeria.

Akinpelu, J. A. (1992). Mass literacy's weapons for sustainable development; A paper presented at the 1992 Launching of the International Literacy Day Celebration and the Launching of the National Mass Literacy Campaign and Fund, Abuja, Nigeria. 
Aromolaran, O. F. (2010). Influence of indigenous vocational education programmes on socio - economic empowerment of women in south western Nigeria. An unpublished $\mathrm{PhD}$ thesis in the department of Adult Education, University of Ibadan.

Benin Business Diary Annual (2015). The social and economic dynamics of Edo state. Benin Socio-economic Life Journal, 1(1) 14, 22-30.

Bhasin, K. (1985). Why and how literacy for women: Some thoughts in the Indian context. Adult Education and Development.

Fadeiye, J. O. \& Olanegan, C. E. (2001). Education Empowerment. Journal of Education Development (JONED)3 (3): 226 -237.

Fadeyi, O.T. (1995). The impact of literacy and non-formal education on women empowerment in Oyo state of Nigeria. An unpublished Ph.D thesis University of Ibadan.

Fasokun, T.O. (2008). The Role of Education in Poverty Eradication In M. Boucouvalas \& R. Aderinoye (Eds). Education for Millenium Development. Essays in Hoour of Professor Michael Omolewa, Ibadan, Spectrum Books Ltd. I: 459-475.

Haijia Abaji, R. E. M. (2008). Education and Empowerment of Women in Nigeria. In M. Boucouvalas \& R. Aderinoye (Eds). Education for Millenium Development. Essays in Honour of Professor Michael Omolewa, Ibadan, Spectrum Books Ltd. II: 104-117.

Ijere, M.O. (2001). The Challenges of rural development in Nigeria. In A.I Ikenne(Ed). The Challenges of Agricultural in National Development, Enugu, Optimal Computer solutions, Ltd.

Karl, M. (1995). Women and Empowerment, Participation and Decision Making. London: Zed Books Ltd.

Kester, K. O. \& Ghenro, A. I. (2008). The Education For All (EFA) Goals and Gender Equality in Educational Opportunities in Nigeria: An overview. In M. Boucouvalas \& R. Aderinoye (Eds). Education for Millenium Development. Essays in Honour of Professor Michael Omolewa, Ibadan, Spectrum Books Ltd. II: 78-92.

Kwapong, D.T.F. (2005). Using Adult education for empowerment of rural women, Adult Education and Development. IIZDW Institute for International Cooperation of the Germany, Adult Education Association, 65: 135-152.

McDowell, M. (1985). Women in Development in the decade for women; Special Report Toronto Canadian Congress for Learning Opportunities for Women.

National Population Commission (2011). Nigeria DHS Ed Data Survey 2010. Abuja: National Population Commission.

Nigel, H. \& Werner M. (2001). 'Gender and HIV/AIDS: A report of the International Workshop on the development of empowering educational HIV/AIDS prevention strategies and gender sensitive materials (7)'. Uduigumen, A. F. 2004. "A philosophy 
of Education for Nigerian Women, Problems and Prospects. The African Symposium Vol.4 No.1 March. (Online available at http://www.wudo.men.html.

Ojobor J. A. (2008). Education; a catalyst for women empowerment in Nigeria. Journal of Education and Science, 4 (1): 93-106.

Okeke, E. A. C. (1995). Women empowerment and rural development in Nigeria (Ed), Eboh, E.C. Okoye, C.V. and Ayichi D. Auto Century Publishing Company: Enugu.

Olaleye, F. O. (2008). Empowering women through education. In M. Boucouvalas \& R. Aderinoye (Eds). Education for Millenium Development. Essays in Honour of Professor Michael Omolewa, Ibadan, Spectrum Books Ltd. II: 153-168.

Olomukoro, C. O. (2014). Towards Achieving Gender Equity in Educational Participation Journal of Educational Research and Development. 8(2), 67-78.

Opeke, K. (2008). Gender in Nigerian education. In M. Boucouvalas \& R. Aderinoye (Eds). Education for Millenium Development. Essays in Honour of Professor Michael Omolewa, Ibadan, Spectrum Books Ltd. II: 3-19

Osokoya, I. O. (2008). Towards Maximizing Women's Contribution to National Development through Education in Nigeria. In M. Boucouvalas \& R. Aderinoye (Eds.). Education for Millenium Development. Essays in Honour of Professor Michael Omolewa, Ibadan, Spectrum Books Ltd. II: 68-76.

Osuala, E. C. (1981). A Handbook of vocational technical education for Nigeria. D. Pacific Publishers. Retrieved January, 2011.

Salami, L \& Uko-Aviomah, E. E. (2005). Enhancing Women's Education as a means of Reducing Poverty in Nigeria. Nigerian Journal of Adult and Lifelong Learning. An Official Journal of the Department of Adult and Non-formal Education, University of Benin, Benin-City, Nigeria, 1(1): 116-127.

Singh, R. (1985). Adult education and rural development. Adult Education and Development II2DVV Institute for International Cooperation of the Germany Adult Education Association. No. 24.

UNESCO, (2003). Millennium Project http.//wwwuunmilleniumproject.org.

UNESCO Education for All Global Monitoring Report (2008). 'Education for all by 2015'. Paris: UNESCO

UNICEF (2002). 'Girls' Education in Nigeria'

United Nations (1985). Implementation of the Nairobi Forward- Looking Strategies for the Advancement of Women. United Nations A/RES/40/108, General Assembly, 13 December $1985,116^{\text {th }}$ Plenary Meeting. www.UN-Documents.net/NFLSAW.htm 
Women Watch (2005). Information and Resources on gender equality and empowerment of women. Education and training of women and the girl-child sponsored by UNESCO and UNICEF, $10^{\text {th }}$ January- $4^{\text {th }}$ February. 